\title{
Faktor Penentu Kinerja Investasi Asuransi Jiwa Syariah di Indonesia
}

\author{
Nur Indah Hidayati' ${ }^{1}$ Ahmad Baehaqi ${ }^{2}$ \\ 1,2 Program Studi Akuntansi Syariah, STEI SEBI, Indonesia \\ indahnhdyt@gmail.com¹, baehaqi17@gmail.com²
}

Masuk: 20 Agustus 2018; Diterima: 1 Desember 2018; Terbit: 18 Desember 2018

\begin{abstract}
This research aims to find out the influence of company size, liquidity, leverage, volume of capital (VOC), underwriting risk and premium growth towards Investment Yield of sharia life insurance company in Indonesia from 2011 to 2015. Technique of analyzing the data used in this study is panel data regression with level of significance 5\%. The result showed that the most appropriate model for this study is Fixed Effect Model (FEM). Simultaneously, all variables have significant influence towards Investment Yield. The result of partial test of Investment Yield showed that company size and liquidity have negative influence, while leverage, VOC, and premium growth have positive influence towards Investment yield. Underwriting risk has no significant influence towards Investment yield.
\end{abstract}

Keywords: sharia life insurance; performance; investment yield

\begin{abstract}
Abstrak
Penelitian ini bertujuan untuk mengetahui pengaruh company size, likuiditas, leverage, volume of capital (VOC), underwriting risk dan premium growth terhadap Investment Yield perusahaan asuransi jiwa syariah di Indonesia periode 2011-2015. Teknik analisis data yang digunakan adalah regresi data panel dengan tingkat signifikansi 5\%. Hasil analisis data menunjukkan bahwa model yang tepat digunakan dalam penelitian ini adalah Fixed Effect Model (FEM). Secara simultan keenam variabel tersebut berpengaruh signifikan terhadap Investment Yield. Sedangkan secara parsial menunjukkan bahwa company size dan likuiditas berpengaruh negatif signfikan sedangkan leverage, $V O C$ dan premium growth berpengaruh positif signifikan terhadap investment yield. Underwriting risk tidak memiliki pengaruh signifikan terhadap investment yield.
\end{abstract}

Kata Kunci: asuransi jiwa syariah; kinerja; hasil investasi 


\section{PENDAHULUAN}

Kesadaran masyarakat terhadap pentingnya asuransi terus meningkat. Masyarakat semakin mengerti perlunya memiliki jaminan finansial untuk menghindari atau mengalihkan risiko keuangan dalam rangka persiapan menghadapi kejadian-kejadian yang tidak terduga. Hal ini berdampak baik terhadap perkembangan industri asuransi jiwa syariah. Tidak hanya itu, perkembangan dunia usaha juga ikut andil dalam memacu perkembangan industri asuransi jiwa syariah (Sartika \& Adinugraha, 2013).

Selama lebih dari 20 tahun, jumlah perusahaan asuransi jiwa syariah di Indonesia terus bertambah (Karim Consulting Indonesia, 2016). Hingga oktober 2016, terdapat 27 perusahaan asuransi jiwa syariah yang telah beroperasi, terdiri dari 6 asuransi jiwa full syariah dan 21 unit syariah asuransi jiwa konvensional. Jumlah tersebut bertambah dari tahun sebelumnya, 5 asuransi jiwa full syariah dan 19 unit syariah asuransi jiwa konvensional (OJK, 2016). Pertambahan secara jumlah perusahaan di atas diikuti oleh kenaikan jumlah aset, investasi dan kontribusi bruto sekalipun rata-rata pertumbuhan setiap tahunnya masih berfluktuatif.

Sampai Desember 2015, jumlah aset asuransi jiwa syariah tercatat sebesar 21,73 triliun rupiah naik sebesar $17 \%$ dari tahun sebelumnya. Jumlah investasi tercatat sebesar 19,6 triliun naik sebesar 16\% dari tahun sebelumnya, sedangkan kontribusi bruto mengalami penurunan sebesar 1\% dari tahun 2014 sebesar 8,39 triliun menjadi 8,27 triliun rupiah. Meskipun industri asuransi jiwa syariah mengalami perkembangan dari segi jumlah perusahaan, jumlah aset dan jumlah investasi, akan tetapi perkembangan tersebut belum bisa menyaingi pangsa pasar (market share) perusahaan asuransi jiwa konvensional. Market share aset asuransi jiwa syariah tahun 2016 sebesar 5,96\% dari total keseluruhan asuransi jiwa (Statistik Perasuransian OJK, 2016).

Market share di atas masih sangat rendah jika dibandingkan asuransi jiwa konvensional yang saat ini masih mendominasi. Menurut Hasbi dan Suryawardani (2013), rendahnya market share asuransi syariah menandakan masih adanya masalah pada instrumen keuangan syariah, apakah disebabkan karena produk asuransi syariah yang tidak menarik atau karena kinerja perusahaan asuransi syariah yang rendah sehingga masyarakat masih belum percaya terhadap asuransi berbasis syariah. Market share sendiri sebenarnya dapat ditingkatkan dengan melakukan kinerja terbaik melalui pemanfaatan sumber daya yang dimiliki oleh perusahaan.

Jika diperhatikan, penurunan jumlah kontribusi bruto pada tahun 2015 tidak berpengaruh terhadap pertumbuhan aset dan investasi. Padahal, pertumbuhan atau penurunan kontribusi bruto harusnya dapat menambah nilai investasi dan aset perusahaan. Hal ini karena kontribusi merupakan transaksi untuk dana peserta yang mencakup investasi ataupun fee (ujrah) yang dibayarkan untuk pengelola (Bayinah, Mardian, Mulyati, \& Maulidha, 2017). Pertambahan nilai investasi baik dari kontribusi ataupun hasil investasi akan meningkatkan jumlah aset asuransi jiwa syariah sehingga market share juga ikut naik.

Karim Consulting Indonesia (2016), memperkirakan asuransi jiwa syariah hanya tumbuh pada tahun 2017 dengan tambahan aset sebesar 7.1 triliun. Jika dilihat dari channel of distribution asuransi jiwa syariah, sebagian besar tambahan aset 7.1 triliun tersebut berasal dari produk unit link. Produk unit link merupakan produk asuransi yang mengkaitkan (linked) produk asuransi jiwa dengan instrumen investasi. Tujuannya adalah 
sebagai produk alternatif yang memberikan keleluasaan bagi para pemegang polis untuk mengakses secara langsung keuntungan investasinya (Sartika \& Adinugraha, 2013). Dengan demikian, investasi merupakan komponen penting dalam pertumbuhan asuransi jiwa syariah. Asuransi jiwa syariah tidak hanya berperan sebagai lembaga intermediari, tetapi juga berperan besar sebagai lembaga investasi (investor institution).

Di tengah dinamika persaingan yang tinggi saat ini, sebuah tantangan besar bagi industri untuk mencapai pertumbuhan yang menguntungkan dalam rangka meningkatkan kinerja. Hal ini memerlukan strategi yang baik untuk meningkatkan keuntungan (Bawa $\&$ Chattha, 2013). Strategi awal yang dapat dilakukan adalah dengan melakukan evaluasi dan menilai kinerja keuangan dengan melihat tingkat profitabilitas dari laporan keuangan perusahaan (Stiawan, 2009). Pengukuran kinerja dapat menghasilkan informasi yang berguna terkait dengan aliran dana, penggunaan dana, termasuk efektivitas dan efesiensi dalam penggunaan dana tersebut. Dengan mengevaluasi kinerja, perusahaan dapat melihat kondisi perusahaan dan perkembangannya pada waktu tertentu (Almajali, Alamro, \& Al-Soub, 2012).

Tidak banyak penelitian yang dilakukan untuk menyelidiki faktor penentu kinerja investasi asuransi jiwa syariah, khususnya di Indonesia. Penelitian sebelumnya lebih banyak mengkaji faktor penentu profitabilitas yang diukur oleh return on asset (ROA) pada perusahaan asuransi secara umum. Penelitian Malik (2011) mengenai profitabilitas perusahaan asuransi di Pakistan menjelaskan bahwa size (ukuran perusahaan) dan volume of capital berpengaruh positif terhadap ROA. Sedangkan leverage ratio dan loss ratio berpengaruh negatif. Sementara, age of company tidak memiliki pengaruh terhadap ROA. Hal ini menjelaskan bahwa size dan volume of capital merupakan faktor penting dalam menentukan kinerja perusahaan asuransi.

Almajali, et al (2012) meneliti kinerja keuangan perusahaan asuransi di Yordania yang terdaftar di Amman Stock Exchange (ASE). Hasil dari penelitiannya menunjukkan leverage, liquidity, size, management competence index (indeks kompetensi manajemen) berpengaruh positif terhadap ROA. Hasil ini berarti variabel-variabel tersebut merupakan faktor penting dalam menentukan kinerja keuangan perusahaan asuransi di Yordania. Hussain (2015) juga meneliti profitabilitas perusahaan asuransi (termasuk takaful) di Pakistan dengan menambahkan variabel makro ekonomi. Hasil penelitian menjelaskan bahwa leverage, working capital, diversification berpengaruh positif terhadap ROA. Sementara, variabel makroekonomi yang digunakan tidak memiliki pengaruh terhadap profitabilitas takaful.

Di Indonesia, Nurlatifah dan Mardian (2016) menggunakan ROA dan Surplus On Contribution (SOC) untuk mengukur kinerja keuangan. Hasil penelitian menunjukkan bahwa size berpengaruh signifikan positif sedangkan leverage, liquidity, tangibility, volume of capital dan loss ratio tidak berpengaruh signifikan terhadap ROA. Sementara kinerja keuangan yang diukur dengan SOC memiliki hasil bahwa size berpengaruh signifikan positif terhadap SOC. Sedangkan, leverage dan volume of capital berpengaruh signifikan negatif dan variabel lainnya yaitu liquidity, tangibility dan loss ratio tidak berpengaruh signifikan terhadap SOC.

Sejalan dengan pentingnya peran investasi dalam perusahaan asuransi jiwa syariah. Maka penelitian ini bermaksud untuk menganalisis faktor-faktor yang mempengaruhi kinerja investasi asuransi jiwa syariah di Indonesia dengan menggunakan variabel- 
variabel yang berpengaruh positif pada penelitian sebelumnya. Dalam penelitian ini, ROA tidak digunakan sebagai pembeda dari penelitian sebelumnya. Pentingnya melakukan penelitian ini, selain untuk mengisi kesenjangan dalam memahami faktorfaktor yang mempengaruhi kinerja keuangan adalah juga untuk mengevaluasi kinerja keuangan asuransi jiwa syariah dan faktor-faktor yang mempengaruhinya mengingat besarnya bagian investasi dalam kontribusi yang diterima dari peserta.

\section{Asuransi Syariah}

Sesuai Fatwa DSN No.21 tahun 2001, asuransi syariah adalah usaha saling melindungi dan tolong menolong di antara sejumlah orang/pihak melalui investasi dalam bentuk aset dan atau tabarru' yang memberikan pola pengembalian untuk menghadapi risiko tertentu melalui akad yang sesuai dengan syariah. Sedangkan dalam UU No. 40 tahun 2014 tentang perasuransian, disebutkan bahwa asuransi syariah merupakan kumpulan perjanjian, yang terdiri atas perjanjian antara perusahaan asuransi syariah dan pemegang polis, dalam rangka pengelolaan kontribusi berdasarkan prinsip syariah guna saling menolong dan melindungi.

Dari pengertian di atas dapat disimpulkan bahwa operasional asuransi syariah berdasarkan pada konsep saling menanggung risiko (risk sharing) antar peserta asuransi yang tergabung dengan melakukan pembayaran kontribusi dana tabarru' dan/atau dana investasi. Sedangkan perusahaan hanya sebagai pihak pengelola dana kontribusi dengan mendapatkan upah/ujrah atas pengelolaan dana dan atau bagi hasil atas hasil investasi. Hal tersebut berbeda dengan asuransi konvensional, dimana perusahaan yang menanggung risiko (risk transfer) peserta asuransi.

\section{Kinerja Investasi: Invesment Yield Ratio}

Kinerja (performance) adalah gambaran mengenai tingkat pencapaian pelaksanaan suatu kegiatan/program dalam mewujudkan sasaran dan tujuan dari suatu organisasi. Kinerja perlu diukur (measured) untuk menilai kemajuan suatu pekerjaan terhadap sasaran dan tujuan yang telah ditentukan sebelumnya. Melakukan evaluasi terhadap kinerja investasi merupakan kegiatan analisis yang penting, terutama bagi perusahaan yang bagian terbesar labanya berasal dari pendapatan investasi. Kinerja investasi adalah salah satu faktor penting atas keberhasilan bank, perusahaan asuransi dan lembaga keuangan lainnya (Subramanyam \& Wild, 2011).

Industri asuransi berperan sebagai pengelola dana masyarakat dalam jumlah besar yang sangat bergantung pada keberhasilan mengelola investasi untuk mewujudkan tujuan perusahaan (Reshid, 2015; Sula, 2004). Asuransi jiwa syariah melakukan portofolio investasi untuk mendapatkan hasil optimal dengan meminimalkan risiko yang ada. Oleh karena itu, sebagian besar keuntungan asuransi jiwa syariah berasal dari hasil investasi. Keuntungan dari hasil investasi tersebut menjadi milik perusahaan, kecuali sumber investasi berasal dari peserta maka dilakukan bagi hasil antara perusahaan dengan peserta sebagaimana yang telah diperjanjikan (Sula, 2004).

Untuk menilai kemampuan manajemen dalam membuat kebijakan investasi, serta menentukan sehat tidaknya perusahaan asuransi dapat diketahui dari rasio hasil investasi (investment yield ratio). Rasio ini merupakan perbandingan antara pendapatan investasi dengan rata-rata investasi. Rata-rata investasi adalah jumlah investasi tahun berjalan 
dan investasi tahun sebelumnya dibagi dua (Dhaniati, 2011). Rasio ini mengacu pada keuntungan yang diterima, hasil yang lebih tinggi menunjukkan pendapatan yang lebih tinggi dan ini bisa menjadi alat pemasaran untuk menarik lebih banyak peserta untuk berkontribusi pada dana asuransi syariah (Htay, Arif, Soualhi, Zaharin, \& Shaugee, 2013).

\section{Kerangka Pemikiran}

Penelitian ini menggunakan variabel independen yaitu company size, likuiditas, leverage, volume of capital, underwriting risk dan premium growth. Sedangkan variabel dependen sebagai profitabilitas diukur Investment Yield. Penelitian ini mengidentifikasi bagaimana variabel-variabel tersebut menentukan investment yield dalam perusahaan asuransi jiwa syariah di Indonesia.

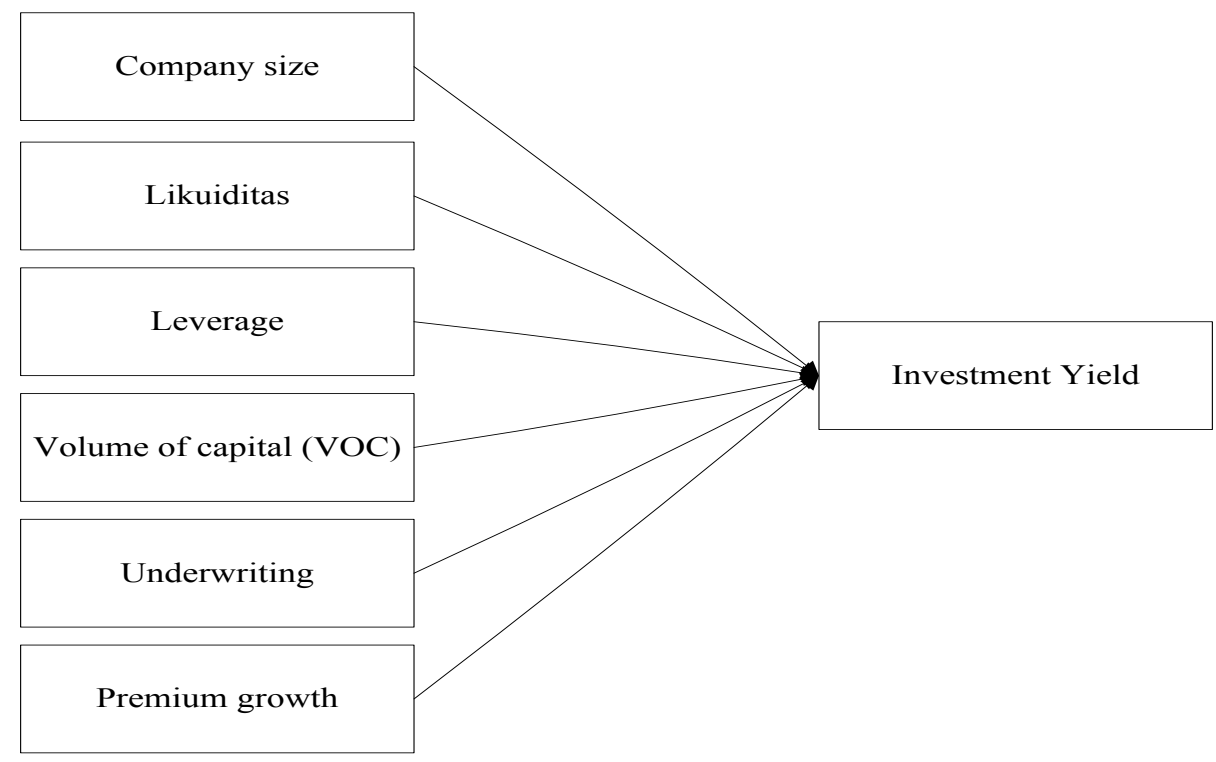

Gambar 1. Hubungan antara Investment Yield dan Faktor Penentunya

\section{Pengembangan Hipotesis}

\section{Pengaruh Company Size Terhadap Kinerja Investasi}

Ukuran perusahaan dihitung sebagai logaritma natural dari total aset perusahaan asuransi. Besarnya ukuran perusahaan diperkirakan dapat mempengaruhi tingkat pengembalian lebih cepat karena memiliki lebih banyak sumber daya yang dapat digunakan untuk mempekerjakan manajer dalam memaksimalkan laba atas aset yang diinvestasikan. Selain itu, perusahaan dengan ukuran besar memiliki diversifikasi risiko yang lebih baik, sistem informasi dan manajemen biaya yang lebih baik dibandingkan perusahaan dengan ukuran kecil (Adams, 1996; Reshid, 2015).

\section{H1: Company size berpengaruh positif terhadap kinerja investasi perusahaan asuransi jiwa syariah}




\section{Pengaruh Likuiditas Terhadap Kinerja Investasi}

Likuiditas merupakan pengukuran untuk menilai posisi keuangan jangka pendek dengan menghitung current ratio (aset lancar dibagi dengan kewajiban lancar). Likuiditas memiliki peran penting dalam mempertimbangkan dampak dari ketidakmampuan perusahaan dalam memenuhi kewajiban jangka pendek. Kurangnya likuiditas menghalangi perusahaan untuk memperoleh keuntungan. Ketidakmampuan perusahaan untuk memenuhi kewajiban lancarnya merupakan masalah yang dapat mengarah pada hasil investasi dan aset lainnya yang dipaksakan, kemungkinan yang paling ekstrem mengarah pada insolvabilitas dan kebangkrutan (Hery, 2015; Subramanyam \& Wild, 2011).

\section{H2: Likuiditas berpengaruh positif terhadap kinerja investasi perusahaan asuransi jiwa syariah}

\section{Pengaruh Leverage Terhadap Kinerja Investasi}

Leverage keuangan mengacu pada jumlah pendanaan utang dalam struktur modal suatu perusahaan. Perusahaan menggunakan modal ekuitas sebagai dasar pinjaman untuk mendapatkan tingkat pengembalian (Subramanyam \& Wild, 2011). Perusahaan yang sangat leverage, memiliki risiko kebangkrutan jika pihak manajemen tidak mampu untuk mengelolanya dengan baik sehingga tidak bisa melakukan pembayaran utang. Tetapi leverage tidak selalu berdampak buruk apabila perusahaan mengelolanya dengan baik (Almajali, et al, 2012).

\section{H3: Leverage berpengaruh positif terhadap kinerja investasi perusahaan asuransi jiwa syariah}

\section{Pengaruh Volume of Capital (VOC) Terhadap Kinerja Investasi}

VOC merupakan ukuran dari nilai buku ekuitas yang akan digunakan sebagai ukuran modal dan diukur dengan log natural dari nilai buku ekuitas (Malik, 2011). Nilai buku memberikan informasi tentang nilai bersih sumber daya yang dimiliki perusahaan. Nilai ekuitas mengandung dua hal yaitu pendapatan dan nilai buku. Sedangkan, laba merupakan ukuran tingkat pengembalian atas sumber daya yang digunakan perusahaan. Ketika nilai laba tinggi, maka kemungkinan perusahaan akan terus beroperasi dengan menggunakan sumber daya yang dimiliki. Berbagai penelitian juga telah menunjukkan bahwa nilai ekuitas berkaitan dengan laba akuntansi (Burgstahler \& Dichev, 1997).

\section{H4: Volume of Capital (VOC) berpengaruh positif terhadap kinerja investasi perusahaan jiwa asuransi syariah}

\section{Pengaruh Underwriting Risk Terhadap Kinerja Investasi}

Risiko underwriting adalah risiko yang menunjukkan bahwa premi yang dikelola perusahaan asuransi tidak mencukupi untuk menutupi biaya. Terutama biaya klaim yang akan digunakan sebagai pertanggungan kepada pemegang polis asuransi dan biaya yang digunakan untuk mengelola kebijakan perusahaan. Menurut Adams (1996), risiko 
underwriting dapat dihindari dengan memaksimalkan pendapatan atas hasil investasi atau langkah-langkah manajemen risiko lainnya. Perusahaan asuransi harus mengelola risiko underwriting dengan baik agar profitabilitas tetap tinggi.

\section{H5: Underwriting risk berpengaruh negatif terhadap kinerja investasi perusahaan asuransi jiwa syariah}

\section{Pengaruh Premium Growth Terhadap Kinerja Investasi}

Unsur premi pada asuransi jiwa syariah terdiri dari unsur tabarru' dan tabungan. Dana premi yang terkumpul akan diinvestasikan dan hasilnya akan dibagikan secara proporsional antara peserta dan perusahaan berdasarkan skim bagi hasil yang telah ditentukan (Sula, 2004). Menurut Reshid (2015), pendapatan premi merupakan sumber pendapatan utama bagi sebagian besar perusahaan asuransi dan umumnya menjadi sumber paling besar diantara sumber pendapatan lainnya. Oleh karena itu, pertumbuhan premi dapat membantu untuk memprediksi pertumbuhan pendapatan dan laba di masa mendatang.

\section{H6: Premium growth berpengaruh positif terhadap kinerja investasi perusahaan asuransi jiwa syariah}

\section{METODE PENELITIAN}

Penelitian ini bertujuan untuk memberikan bukti empiris mengenai faktor- faktor yang mempengaruhi kinerja investasi asuransi jiwa syariah di Indonesia. Variabel yang diuji terdiri dari company size, likuiditas, leverage, volume of capital (VOC), underwriting risk dan premium growth. Berikut adalah pengukuran variabel yang digunakan dalam penelitian:

Tabel 1. Pengukuran variabel Independen dan Variabel Dependen

\begin{tabular}{|c|c|c|c|}
\hline \multicolumn{2}{|r|}{ Variabel } & Deskripsi / Ukuran & \multirow{2}{*}{$\begin{array}{l}\text { Skala } \\
\text { Rasio }\end{array}$} \\
\hline Dependen & Investment Yield & $\frac{\text { Investment Income }}{\text { Average Investment }} \times 100$ & \\
\hline \multirow[t]{4}{*}{ Independen } & $\begin{array}{l}\text { Company Size } \\
\text { Liquidity }\end{array}$ & $\begin{array}{l}\text { Log natural total aset } \\
\frac{\text { Current Asset }}{\text { Current Libilities }} \times 100\end{array}$ & $\begin{array}{l}\text { Rasio } \\
\text { Rasio }\end{array}$ \\
\hline & Leverage & $\frac{\text { Total Utang }}{\text { Total Asset }} \times 100$ & Rasio \\
\hline & $\begin{array}{l}\text { Volume of Capital } \\
\text { Underwriting Risk }\end{array}$ & $\begin{array}{l}\text { Log natural nilai buku ekuitas } \\
\frac{\text { Net Insurance Claim }}{\text { Net Premi }} \times 100\end{array}$ & $\begin{array}{l}\text { Rasio } \\
\text { Rasio }\end{array}$ \\
\hline & Premium Growth & $\frac{\mathrm{GWP}_{\mathrm{t}}-\mathrm{GWP}_{\mathrm{t}-1}}{\mathrm{GWP}_{\mathrm{t}-1}}$ & Rasio \\
\hline
\end{tabular}

Sumber: Data diolah (2017) 
Populasi dalam penelitian ini adalah perusahaan asuransi jiwa syariah di Indonesia per Desember 2015, baik yang sudah full fledge maupun yang masih berbentuk unit syariah berjumlah 24 perusahaan. Adapun pengambilan sampel menggunakan teknik purposive sampling dengan kriteria perusahaan asuransi jiwa syariah yang beroperasi dan mempublikasikan laporan keuangan tahunan secara berturut-turut selama tahun 20102015. Berdasarkan kriteria tersebut, maka sampel perusahaan asuransi jiwa syariah yang dijadikan objek penelitian berjumlah 11 perusahaan. Data utama dan penunjang pada penelitian berupa data sekunder yang diperoleh melalui buku, website resmi perusahaan asuransi jiwa syariah, website resmi lainnya, dan literatur penunjang lainnya.

Metode analisis data yang digunakan adalah analisis regresi data panel (panel data multiple regression). Data panel merupakan gabungan antara data yang terdiri atas beberapa objek (cross section) dan data berdasarkan runtun waktu (time series) (Gujarati, 2004). Menurut Gujarati (2004), penggunaan data panel dapat memberikan data yang lebih informatif, lebih bervariasi, sedikit kolinieritas antar variabel, lebih banyak menghasilkan degree of freedom (df) dan lebih efisien. Penelitian ini menggunakan 11 perusahaan asuransi jiwa syariah dengan periode 2011-2015 sebagai sampel penelitian serta 6 variabel independen (company size, likuiditas, leverage, volume of capital, underwriting risk, premium growth).

Persamaan regresi yang digunakan adalah:

$$
I Y_{i}=\beta_{0}+\beta_{1} S Z+\beta_{2} \text { Likuid }+\beta_{3} L e v+\beta_{4} V O C+\beta_{5} U R+\beta_{6} P G+e
$$

Penelitian ini menggunakan software Eviews 9 untuk mengolah data yang sudah didapatkan melalui dokumentasi maupun empirical research guna mendapatkan kesimpulan penelitian. Sebelum pengujian hipotesis dilakukan, dilakukan uji asumsi klasik terlebih dahulu dan pemilihan model regresi panel. Tiga model regresi panel yaitu Common Effect Model (CEM), Fixed Effect Model (FEM), dan Random Effect Model (REM) akan dipilih model yang digunakan melalui uji Chow dan uji Hausman.

\section{HASIL DAN PEMBAHASAN}

\section{Hasil Uji Asumsi Klasik}

Berdasarkan pengujian, berikut ini adalah hasil uji asumsi klasik; Pertama, uji normalitas dilakukan untuk mengetahui apakah data terditribusi normal atau tidak, data yang tidak terdistribusi normal akan mengakibatkan hasil uji statistik menjadi tidak valid (Ghazali \& Ratmono, 2013). Hasil uji normalitas menunjukkan bahwa nilai probabilitas Jarque-Bera 0.93833 lebih besar dari nilai signifikansi 0.05 (5\%). Maka $\mathrm{H}_{0}$ tidak ditolak yang artinya data yang digunakan terdistribusi dengan normal.

Kedua, uji multikolinearitas bertujuan untuk mendeteksi adanya korelasi yang tinggi atau sempurna antarvariabel independen dalam model regresi. Asumsi dari pengujian ini untuk menyatakan bahwa model regresi tidak terjadi multikolinearitas. Multikolinearitas dapat dideteksi dengan Variance Inflation Factor (VIF). Nilai yang digunakan untuk menunjukkan adanya multikolinearitas adalah lebih dari 10 (Ghazali \& Ratmono, 2013). Hasil uji multikolinieritas menunjukkan bahwa nilai VIF untuk variabel company size sebesar 3.9501, likuiditas sebesar 1.2132, leverage sebesar 1.4535, VOC 
sebesar 3.7241, underwriting risk sebesar 1.4483 dan premium growth sebesar 1.2787. Keenam variabel tersebut memiliki nilai VIF $<10$, maka dapat disimpulkan bahwa model regresi tidak terjadi multikolinearitas.

Ketiga, uji heteroskedastisitas bertujuan untuk mendeteksi bahwa varian dari variabel gangguan adalah konstan. Ada beberapa jenis pengujian yang dapat dilakukan untuk mendeteksi adanya heteroskedastisitas seperti uji Glejser, Harvey, White, Breusch Pagan Godfrey (Ghazali \& Ratmono, 2013). Penelitian ini menggunakan uji White untuk mendeteksi adanya heteroskedastisitas. Berikut adalah hasil uji heteroskedastisitas dengan uji White:

Tabel 2. Hasil Uji Heteroskedastisitas (Investment Yield)

\begin{tabular}{|c|c|c|c|}
\hline \multicolumn{4}{|c|}{ Heteroskedasticity Test: White } \\
\hline F-statistic & 1.056461 & Prob. F(6,33) & 0.4079 \\
\hline Obs*R-squared & 6.445314 & Prob. Chi Square(6) & 0.3752 \\
\hline Scaled explained SS & 4.741041 & Prob. Chi-Square(6) & 0.5774 \\
\hline
\end{tabular}

Note: nilai probabilitas Obs*R-squared $0.3752>0.05$.

Berdasarkan tabel di atas, maka $\mathrm{H}_{0}$ tidak ditolak yang artinya data yang digunakan tidak mengandung masalah heteroskedastisitas. Keempat, model regresi yang baik adalah regresi yang terbebas dari autokorelasi. Autokorelasi muncul karena observasi yang berurutan sepanjang waktu berkaitan satu sama lain. Penelitian ini menggunakan uji Lagrange Multiplier (LM Test) untuk mendeteksi adanya autokorelasi. Berikut ini adalah hasil uji autokorelasi dengan uji LM:

Tabel 3. Hasil Uji Autokorelasi (Investment Yield)

\begin{tabular}{llll}
\hline \multicolumn{4}{l}{ Breusch-Godfrey Serial Correlation LM Test: } \\
\hline F-statistic & 4.651043 & Prob. F(2,31) & 0.0171 \\
Obs*R-squared & 9.232362 & Prob. Chi-Square(2) & 0.0699 \\
\hline
\end{tabular}

Note: nilai probabilitas Chi-Square sebesar 0.0699 $>0.05$.

Berdasarkan tabel di atas, maka $\mathrm{H}_{0}$ tidak ditolak yang artinya data tidak mengandung masalah autokorelasi.

\section{Pemilihan Model Regresi Data Panel}

Uji F-stat (Uji Chow) digunakan untuk menguji model terbaik antara Common Effect Model dengan Fixed Effect Model. Berikut adalah hasil dari pengujian F-stat:

Tabel 4. Hasil Redundant Fixed Effect

\begin{tabular}{lccc}
\hline Effects Test & Statistic & d.f. & Prob. \\
\hline Cross-section F & 25.9563 & $(10,22)$ & 0.0000 \\
Cross-section Chi-square & 99.4232 & 10 & 0.0000 \\
\hline
\end{tabular}

Note: nilai probabilitas Cross-section F dan Cross-section Chi-square $<5 \%$. 
Berdasarkan tabel di atas, maka model yang terpilih adalah Fixed Effect Model (FEM). Namun hasil ini belum merupakan hasil akhir, perlu dilakukan pengujian Hausman test untuk membandingkan Fixed Effect Model dengan Random Effect Model. Berikut ini adalah hasil dari uji Hausman:

Tabel 5. Hasil The Hausman Specification Test

\begin{tabular}{cccc}
\hline Test Summary & Chi-Sq. Statistic & $\begin{array}{c}\text { Chi-Sq. } \\
\text { d.f. }\end{array}$ & Prob. \\
\hline Cross-section random & 14.2375 & 6 & 0.0271 \\
\hline
\end{tabular}

Note: nilai probabilitas cross-section random $<5 \%$.

Berdasarkan hasil uji Hausman diatas, maka Fixed Effect Model (FEM) adalah model yang baik untuk dijadikan model penelitian. Adapun persamaan regresi dari hasil estimasi Fixed Effect Model adalah sebagai berikut:

\section{Investment Yield $=-8.4521-0.9989 \mathrm{SZ}-0.0325$ LIKUID $+3.5102 \mathrm{LEV}+1.5051$ VOC - 0.1067 UR + 0.0980 PG}

Nilai konstanta Investment Yield adalah -8.4521. Angka ini menunjukkan bahwa jika variabel company size, likuiditas, leverage, VOC, underwriting risk dan premium growth adalah tetap (konstan) maka akan menurunkan Investment Yield sebesar 8.4521.

\section{HASIL PENGUJIAN HIPOTESIS DAN PEMBAHASAN}

\section{Koefisien Determinasi (R2)}

Hasil uji koefisien determinasi pada tabel 6 adalah sebesar 0.958398 (96\%). Angka ini menerangkan kekuatan variasi variabel independen terhadap variabel dependen. Hasil ini menunjukkan bahwa variasi dari variabel dependen (Investment Yield) 96\% dapat diterangkan oleh variabel independen (company size, likuiditas, leverage, VOC, underwriting risk dan premium growth). Sedangkan sisanya 4\% diterangkan oleh variabel lain yang tidak dijelaskan dalam penelitian ini.

\section{Uji-F (Simultan)}

Uji-F digunakan untuk mengetahui apakah variabel independen yaitu company size, likuiditas, leverage, VOC, underwriting risk dan premium growth secara bersamasama berpengaruh atau tidak terhadap variabel dependen Investment Yield. Hasil Uji F pada tabel 6 menunjukkan bahwa nilai F-Statistik $<5 \%$ yang berarti $\mathrm{H}_{0}$ ditolak. Dapat disimpulkan bahwa variabel independen yaitu company size, likuiditas, leverage, VOC, underwriting risk dan premium growth secara bersama-sama akan mempengaruhi Investment Yield perusahaan asuransi jiwa syariah.

\section{Uji-t (Parsial)}

Berikut ini adalah hasil uji t dari Fixed Effect Model dengan menggunakan eviews 9: 
Tabel 6. Fixed Effect Model

\begin{tabular}{|c|c|c|c|c|}
\hline Variable & Coefficient & Std. Error & t-Statistic & Prob. \\
\hline X1_SZ & - 0.9989 & 0.3316 & -3.0122 & 0.0064 \\
\hline X2_LIKUID & 0.0325 & 0.0068 & 4.8073 & 0.0001 \\
\hline X3_LEV & 3.5102 & 0.5181 & 6.7758 & 0.0000 \\
\hline $\mathrm{X} 4$ _ VOC & 1.5051 & 0.3071 & 4.9002 & 0.0001 \\
\hline X5_UR & 0.1067 & 0.1755 & 0.6080 & 0.5494 \\
\hline X6_PG & 0.0980 & 0.0299 & 3.2797 & 0.0034 \\
\hline $\mathrm{C}$ & -8.4521 & 1.0621 & -7.9579 & 0.0000 \\
\hline \multicolumn{5}{|c|}{ Effects Specification } \\
\hline \multicolumn{5}{|c|}{ Cross-section fixed (dummy variables) } \\
\hline R-squared & 0.958398 & \multicolumn{2}{|c|}{ Mean dependent var } & -2.913618 \\
\hline Adjusted R-squared & 0.928143 & \multicolumn{2}{|c|}{ S.D. dependent var } & 0.605833 \\
\hline S.E. of regression & 0.162401 & \multicolumn{2}{|c|}{ Akaike info criterion } & -0.498224 \\
\hline Sum squared resid & 0.580228 & \multicolumn{2}{|c|}{ Schwarz criterion } & 0.226918 \\
\hline Log likelihood & 26.71537 & \multicolumn{2}{|c|}{ Hannan-Quinn criter. } & -0.238049 \\
\hline F-statistic & 31.67667 & \multirow{2}{*}{\multicolumn{2}{|c|}{ Durbin-Watson stat }} & 3.335275 \\
\hline Prob(F-statistic) & 0.000000 & & & \\
\hline
\end{tabular}

Note: nilai probabilitas company size $<0.05$, nilai probabilitas likuiditas $<0.05$, nilai probabilitas leverage $<0.05$, nilai probabilitas $\mathrm{VOC}<0.05$, nilai probabilitas underwriting risk $>0.05$, nilai probabilitas premium growth $<0.05$

Berdasarkan tabel diatas maka dapat dilakukan pembahasan terhadap masingmasing variabel sebagai berikut:

\section{Company Size}

\section{$\mathrm{H}_{1}$ : Ukuran perusahaan berpengaruh positif terhadap Investment Yield perusahaan asuransi jiwa syariah.}

Berdasarkan tabel 6 di atas diketahui bahwa $\mathbf{H}_{\mathbf{0}}$ ditolak dan $\mathbf{H}_{1}$ tidak ditolak yang berarti bahwa company size berpengaruh signifikan negatif terhadap Investment Yield perusahaan asuransi jiwa syariah di Indonesia. Hasil penelitian ini bertentangan dengan pernyataan Farrell dalam Gumanti (2011) yang menyatakan bahwa teori portofolio mencakup bagaimana perusahaan melakukan alokasi aset. Ketika pihak manajemen memiliki pemahaman yang baik terhadap teori investasi, maka perusahaan akan mampu untuk melakukan alokasi aset dengan baik. Menurut Mehari dan Aemiro (2013) dalam penelitiannya, perusahaan asuransi dengan ukuran besar akan melakukan kinerja lebih baik dari perusahaan dengan ukuran kecil. Hal ini karena mereka bisa mencapai efisiensi biaya operasional melalui peningkatan output dan penghematan biaya inovasi produk. Selain itu, secara efektif perusahaan asuransi telah melakukan diversifikasi risiko portofolio yang baik.

Pengaruh negatif antara company size dan investment yield memiliki makna bahwa semakin besar total aset yang dimiliki perusahaan maka semakin kecil hasil investasi. Berdasarkan teori yang telah dipaparkan menunjukkan bahwa ketika company size dan investment yield memiliki pengaruh signifikan negatif, maka dapat disebabkan 
perusahaan tidak mampu mengelola investasi dengan baik, sehingga berdampak pada kegagalan diversifikasi risiko yang telah diestimasi. Selain itu, menurut Rikalmi dan Wibowo (2014) dalam penelitiannya, perusahaan dengan ukuran besar tidak menjamin bahwa perusahaan tersebut dapat menghasilkan profitabilitas yang tinggi. Sebaliknya, perusahaan dengan ukuran kecil belum tentu akan menghasilkan profitabilitas yang kecil juga.

\section{Likuiditas}

\section{$\mathrm{H}_{2}$ : Likuiditas berpengaruh positif terhadap Investment Vield perusahaan asuransi jiwa syariah.}

Berdasarkan tabel 6 diketahui bahwa $\mathbf{H}_{\mathbf{0}}$ ditolak dan $\mathbf{H}_{2}$ tidak ditolak yang berarti bahwa variabel likuiditas memiliki pengaruh negatif signifikan terhadap Investment Yield perusahaan asuransi jiwa syariah di Indonesia. Pengaruh negatif antara likuiditas dan investment yield memiliki makna bahwa ketika likuiditas meningkat maka akan menurunkan tingkat investment yield. Hal ini menunjukkan bahwa ketika likuiditas tinggi artinya perusahaan menempatkan dana yang besar pada sisi aset lancar. Keadaan ini menyebabkan dua hal yang berlainan yaitu di satu sisi likuiditas yang tinggi menunjukkan perusahaan yang semakin likuid. Di sisi lain, mengurangi kesempatan perusahaan dalam melakukan investasi yang dapat menghasilkan tingkat pengembalian karena mencadangkan kas untuk memenuhi tingkat likuiditas (Putrawan, Sinarwati, \& Purnamawati, 2015). Dalam hal ini, pihak manajemen perusahaan harus bisa memperkirakan kebutuhan yang paling penting diantara keduanya bagi perusahaan.

Penelitian ini mendukung hasil penelitian Raheman dan Nasr (2007), Putrawan, et al (2015) dan Kaya (2015) yang menyatakan bahwa likuiditas berpengaruh signifikan negatif terhadap profitabilitas. Akan tetapi bertentangan dengan penelitian yang dilakukan Charumathi (2012) yang menyatakan bahwa likuiditas memiliki pengaruh signifikan positif terhadap profitabilitas.

\section{Leverage}

\section{$\mathrm{H}_{3}$ : Leverage berpengaruh positif terhadap Investment Vield perusahaan asuransi jiwa syariah.}

Berdasarkan tabel 6 diketahui bahwa $\mathbf{H}_{0}$ ditolak dan $\mathbf{H}_{3}$ tidak ditolak yang berarti variabel leverage memiliki pengaruh signifikan positif terhadap Investment Yield perusahaan asuransi jiwa syariah di Indonesia. Pengaruh signifikan positif leverage terhadap investment yield memiliki makna bahwa kenaikan leverage akan mempengaruhi kenaikan hasil investasi. Menurut Adams (1996) dalam penelitiannya, perusahaan dengan arus kas tinggi yang berasal dari utang, menjadikan pihak manajer untuk bekerja lebih efektif dalam menghasilkan arus kas, untuk menghindari kerugian atas modal pinjaman yang didapat. Hal ini mempengaruhi pihak manajer dalam membuat keputusan investasi yang lebih baik.

Keadaan ini menunjukkan utang yang terdapat dalam struktur modal perusahaan asuransi jiwa digunakan untuk investasi, sebagaimana karakteristik asuransi jiwa yang sebagian besar keuntungannya berasal dari hasil investasi. Selain itu, keadaan ini menggambarkan pihak manajemen perusahaan membuat keputusan investasi yang baik 
sehingga investasi yang berasal dari tingkat leverage dapat meningkatkan hasil investasi.

\section{Volume Of Capital (VOC)}

\section{$\mathrm{H}_{4}$ : Volume of Capital berpengaruh positif terhadap Investment Yield perusahaan asuransi jiwa syariah.}

Berdasarkan tabel 6 diketahui bahwa $\mathbf{H}_{\mathbf{0}}$ ditolak dan $\mathbf{H}_{\mathbf{4}}$ tidak ditolak yang berarti VOC memiliki pengaruh positif signifikan terhadap investment yield perusahaan asuransi jiwa syariah di Indonesia. Volume of capital diperoleh dari logaritma natural nilai buku ekuitas perusahaan asuransi syariah yang tertera dalam neraca. Pengaruh positif antara VOC dan investment yield memiliki makna bahwa ketika nilai ekuitas meningkat maka hasil investasi akan meningkat. Kondisi ini menunjukkan bahwa sumber daya dalam struktur modal perusahaan asuransi jiwa syariah digunakan secara efektif dan efisien dalam melakukan investasi. Selain itu, peningkatan nilai ekuitas tidak selalu berasal dari nilai penambahan modal, tetapi dapat dilihat dari selisih positif atas penilaian surat berharga (valuasi). Nilai tersebut tertera dalam laporan keuangan perusahaan asuransi syariah dalam komponen ekuitas sebagai kenaikan atau penurunan surat berharga.

\section{Underwriting Risk}

\section{$\mathrm{H}_{5}$ : Underwriting Risk berpengaruh negatif terhadap Investment Yield perusahaan asuransi jiwa syariah.}

Berdasarkan tabel 6 diketahui bahwa $\mathbf{H}_{\mathbf{0}}$ tidak ditolak dan $\mathbf{H}_{5}$ ditolak yang berarti underwriting risk tidak memiliki pengaruh terhadap investment yield perusahaan asuransi jiwa syariah di Indonesia. Underwriting merupakan proses penyelesaian dan pengelompokkan risiko yang akan ditanggung perusahaan asuransi syariah. Salah satu tujuan underwriting adalah memaksimalkan laba melalui penerimaan distribusi risiko yang diperkirakan akan mendatangkan laba. Sedangkan, risiko underwriting adalah risiko yang menunjukkan bahwa premi yang dikelola perusahaan asuransi tidak mencukupi untuk menutupi biaya-biaya, seperti biaya klaim yang digunakan sebagai pertanggungan kepada pemegang polis asuransi dan biaya operasional perusahaan. Apabila perusahaan dapat mengelola risiko underwriting secara efisien, maka hal ini dapat membantu perusahaan dalam menghadapi persaingan dalam dunia bisnis.

Nilai dari underwriting risk dapat diperoleh dari perbandingan antara net insurance claim dengan net premium. Net insurance claim dihitung dari jumlah klaim yang ditanggung pengelola dikurangi dengan jumlah klaim yang ditanggung pihak reasuransi. Sedangkan, net premium dihitung dari jumlah kontribusi dikurangi dengan kontribusi yang ditanggung perusahaan reasuransi.

MenurutAdams (1996) dalam penelitiannya, untuk memilih dan menargetkan risiko yang tepat untuk keseluruhan peserta; mengelola risiko secara keseluruhan; mengelola operasional yang efisien; dapat dihindari dengan memaksimalkan pendapatan atas hasil investasi atau langkah-langkah manajemen risiko lainnya seperti bekerja sama dengan perusahaan reasuransi untuk mengurangi pencairan klaim dalam mengatasi kesulitan keuangan. Hasil penelitian ini menunjukkan bahwa besar kecilnya risiko underwriting tidak mempengaruhi hasil investasi yang diterima perusahaan asuransi jiwa syariah. Keadaan ini menggambarkan risiko underwriting yang dikelola perusahaan asuransi 
syariah didasari oleh tingkat efisiensi pihak manajemen perusahaan dalam membuat kebijakan. Baik itu kebijakan untuk menentukan besarnya premi yang akan dibayarkan pemegang polis asuransi ataupun kebijakan atas penerimaan atau penolakan pengajuan klaim asuransi. Saat biaya klaim terlalu besar maka proporsi dari jumlah kontribusi lebih banyak dialokasikan untuk pembayaran klaim, sehingga perusahaan tidak memiliki kesempatan dalam melakukan investasi untuk mendapatkan keuntungan.

\section{Premium Growth}

\section{$\mathrm{H}_{6}$ : Premium Growth berpengaruh positif terhadap Investment Vield perusahaan asuransi jiwa syariah.}

Berdasarkan tabel 6 diketahui bahwa $\mathbf{H}_{\mathbf{0}}$ ditolak dan $\mathbf{H}_{\mathbf{6}}$ tidak ditolak yang berarti premium growth memiliki pengaruh signifikan positif terhadap investment yield pada perusahaan asuransi jiwa syariah di Indonesia. Pengukuran atas pertumbuhan premi dapat memperlihatkan persentase jumlah pertambahan premi yang dikelola perusahaan asuransi. Nilai pertumbuhan premi diperoleh dari jumlah premi tahun berjalan dikurangi dengan jumlah premi tahun sebelumnya, kemudian dibandingkan dengan jumlah premi tahun sebelumnya.

Premi dalam perusahaan asuransi syariah dikenal dengan istilah kontribusi. Kontribusi dalam perusahaan asuransi syariah terdiri dari dana tabarru' yang digunakan untuk kepentingan peserta dan ujrah untuk kepentingan pengelola (perusahaan asuransi) (Ghoni \& Arianty, 2007). Mekanisme pengelolaan dana pada asuransi syariah berbeda dengan asuransi konvensional. Pada asuransi jiwa, produk yang mengandung unsur tabungan, dana yang dibayarkan peserta langsung dibagi dalam dua rekening, yaitu rekening peserta dan rekening tabarru'. Setelah itu, dana yang terkumpul akan diinvestasikan dan hasilnya akan dibagikan secara proporsional antara peserta dan perusahaan berdasarkan skim bagi hasil yang telah ditentukan.

Sedangkan, pengelolaan dana produk asuransi jiwa yang tidak mengandung unsur tabungan, terjadi akad mudharabah. Total dana kontribusi yang dibayarkan peserta akan diinvestasikan, kemudian hasil investasi setelah dikurangi beban asuransi akan dibagi hasilkan antara peserta dan pengelola sesuai skim yang telah diperjanjikan (Sula, 2004). Hasil penelitian menunjukkan bahwa premium growth memiliki pengaruh signifikan positif terhadap investment yield perusahaan asuransi jiwa syariah. Artinya, ketika pertumbuhan premi mengalami peningkatan maka akan diikuti dengan peningkatan hasil investasi. Hal ini sesuai dengan teori yang telah diuraikan, sebagaimana dana premi/kontribusi pada asuransi jiwa syariah dialokasikan sebagai dana investasi yang dilakukan perusahaan asuransi (pengelola). Kemudian hasilnya akan dibagikan untuk peserta dan pengelola sesuai skim yang telah diperjanjikan.

\section{KESIMPULAN}

Kinerja investasi asuransi jiwa syariah yang diukur dengan investment yield menunjukkan company size, likuiditas, leverage, VOC, underwriting risk dan premium growth secara simultan berpengaruh signifikan terhadap investment yield. Sedangkan, secara parsial, company size, likuiditas, leverage, VOC, dan premium growth terbukti 
secara statistik berpengaruh signifikan terhadap investment yield. Hasil penelitian menunjukkan bahwa leverage, VOC, premium growth berpengaruh positif sedangkan company size dan likuiditas berpengaruh negatif terhadap investment yield. Tetapi variabel underwriting risk tidak berpengaruh signfikan terhadap investment yield perusahaan asuransi jiwa syariah di Indonesia.

Beberapa saran yang dapat peneliti sampaikan berdasarkan analisis yang telah dilakukan adalah penelitian ini hanya menggunakan periode waktu 5 tahun yaitu mulai dari 2011-2015, sebaiknya untuk penelitian berikutnya mencoba menguji dengan menambahkan sampel periode pengamatan yang lebih banyak dan data terbaru guna mendapatkan hasil yang lebih baik. Selain itu, penelitian selanjutnya bisa menambah sampel baik asuransi umum ataupun reasuransi syariah, tidak hanya asuransi jiwa syariah.

\section{DAFTAR PUSTAKA}

Adams, M. (1996). Investment Earnings and the Characteristics of Life Insurance Firms: New Zealand Evidence. Australian Journal of Management, 21 (1), 41-55. http://doi. org/10.1177/031289629602100106

Almajali, A. Y., Alamro, S. A., \& Al-Soub, Y. Z. (2012). Factors Affecting the Financial Performance of Jordanian Insurance Companies Listed at Amman Stock Exchange. Journal of Management Research, 4 (2), 266-289. http://doi.org/10.5296/jmr.v4i2.1482

Bawa, S. K., \& Chattha, S. (2013). Financial Performance of Life Insurers in Indian Insurance Industry. Pacific Business Review International, 6 (5), 44-52.

Bayinah, A. N., Mardian, S., Mulyati, S., \& Maulidha, E. (2017). Akuntansi Asuransi Syariah. Jakarta: Salemba Empat.

Burgstahler, D. C., \& Dichev, I. D. (1997). Earnings, Adaption and Equity Value. The Accounting Review, 72 (2), 187-215. Retrieved from http://80.64.63.173/research/finn-websitesreproduced-permission-copyright-owner-further-reproduction-prohibited-withoutpermission/

Charumathi, B. (2012). On the Determinants of Profitability of Indian Life Insurers - An Empirical Study. Proceedings of The World Congress on Engineering, I, 4-9. London, UK.

Dhaniati, R. (2011). Analisis pengaruh RBC, Rasio Underwriting, Rasio Hasil Investasi, Rasio Penerimaan Premi dan Rasio Beban Klaim terhadap Laba Perusahaan Asuransi. Jurnal Akuntansi, 1 (2).

Ghazali, I., \& Ratmono, D. (2013). Analisis Multivariat dan Ekonometrika Teori, Konsep dan Aplikasi dengan Eviews 8. Semarang: Universitas Diponegoro.

Ghoni, A., \& Arianty, E. (2007). Akuntansi Asuransi Syariah: Antara Teori \& Praktek. Jakarta: Insco Consulting.

Gujarati, D. N. (2004). Basic Econometrics (fourth). New York: The McGraw-Hill. http://doi. org/10.2307/2344828

Gumanti, T. A. (2011). Manajemen Investasi: Konsep, Teori dan Aplikasi (Edisi 1). Jakarta: Mitra Wacana Media.

Hasbi, H., \& Suryawardani, B. (2013). Sistem Peringatan Dini Sebagai Pendukung Kinerja Perusahaan Asuransi Syariah. Jurnal Keuangan dan Perbankan, 17 (2) , 243-252.

Hery. (2015). Analisis Laporan Keuangan. Yogyakarta: PT. Buku Seru.

Htay, S. N. N., Arif, M., Soualhi, Y., Zaharin, H. R., \& Shaugee, I. (2013). Accounting, Auditing and Governance for Takaful Operations. Singapore: John Wiley \& Sons Singapore Pte.

Hussain, I. (2015). Macro Economy And Profitability Of Insurance Companies : A Post Crisis Scenario In Pakistan. Pakistan Business Review, 243-263. 
Karim Consulting Indonesia. (2016). Islamic Insurance Outlook 2017. Jakarta. Retrieved from www.karimcosulting.com

Kaya, E. O. (2015). The Effects of Firm-Specific Factors on the Profitability of Non-Life Insurance Companies in Turkey. International Journal of Financial Studies, 3 (4), 510-529. http:// doi.org/10.3390/ijfs3040510

Malik, H. (2011). Determinants of Insurance Companies Profitability : an Analysis of Insurance Sector of Pakistan. Academic Research International, 1(3), 315-321.

Mehari, D., \& Aemiro, T. (2013). Firm Specific Factors That Determine Insurance Companies'Performance in Ethiopia. European Scientific Journal, 9 (10), 245-255. Retrieved from http://eujournal.org/index.php/esj/article/view/961

Nurlatifah, A. F., \& Mardian, S. (2016). Kinerja Keuangan Perusahaan Asuransi Syariah di Indonesia: Surplus On Contribution. Akuntabilitas: Jurnal Ilmu Akuntansi, 9 (1), 73-96. http://doi.org/10.15408/akt.v9i1.3590

Putrawan, P. W., Sinarwati, N. K., \& Purnamawati, I. G. A. (2015). Pengaruh Investasi Aktiva Tetap, Likuiditas, Solvabilitas dan Modal Kerja terhadap Profitabilitas Perusahaan Otomotif dan Komponen yang Terdaftar di Bursa Efek Indonesia Tahun 2010-2013. JIMAT (Jurnal Ilmiah Mahasiswa Akuntansi), 3 (1).

Raheman, A., \& Nasr, M. (2007). Working Capital Management And Profitability - Case Of Pakistani Firms. International Review of Business Research Papers, 3 (1), 279-300.

Reshid, S. (2015). Determinants of Insurance Companies Profitability in Ethiopia. Thesis: Addis Ababa University. Ethiopia.

Rikalmi, R. T., \& Wibowo, S. S. A. (2014). Pengaruh Ukuran Perusahaan dan Modal Kerja Terhadap Profitabilitas Perusahaan. Jurnal Ilmu dan Riset Manajemen, 7 (10), 11-18

Sartika, M., \& Adinugraha, H. H. (2013). Konsep dan Implementasi Pengelolaan Dana Premi Unit Link Syariah. Jurnal Asuransi dan Manajemen Resiko, 1 (2), 22-38.

Stiawan, A. (2009). Analisis Pengaruh Faktor Makroekonomi, Pangsa Pasar dan Karakteristik Bank Terhadap Profitabilitas Bank Syariah. Semarang: Tesis S 2 Magister Manajemen, Program Pascasarjana Universitas Diponegoro.

Subramanyam, K. R., \& Wild, J. J. (2011). Analisis Laporan Keuangan (10th ed.). Jakarta: Salemba Empat.

Sula, M. S. (2004). Konsep dan Operasional Asuransi Syariah (Life and general). Jakarta: Gema Insani. 